\title{
TEMPORAL INCONSISTENCIES IN COARSE-SCALE SNOW WATER EQUIVALENT PATTERNS: COLORADO RIVER BASIN SNOW TELEMETRY-TOPOGRAPHY REGRESSIONS
}

\author{
Inconsistencias temporales en los patrones espaciales \\ del equivalente de agua en nieve: regresiones entre telemetría \\ de nieve y topografía en la cuenca del río Colorado
}

\author{
S. R. FASSNAChT ${ }^{1 *}$, K. A. Dressler ${ }^{2}$, D. M. Hultstrand ${ }^{1}$, \\ R. C. BALES ${ }^{3}$ AND G. PATTERSON ${ }^{1}$ \\ 1 Watershed Science, Colorado State University, Fort Collins, Colorado 80523-1476 USA \\ 2 Office of Research, Pennsylvania State University, University Park, Pennsylvania 16802 USA \\ 3 University of California, Merced, PO Box 2039, Merced, California 95344 USA \\ * Corresponding author: S. R. Fassnacht: phone: +1.970.491.5454; fax: +1.970.491.1965; \\ email: <steven.fassnacht@colostate.edu>
}

ABSTRACT.- The relation between snow water equivalent (SWE) and 28 variables (27 topographically-based topographic variables and canopy density) for the Colorado River Basin, USA was explored through a multi-variate regression. These variables include location, slope and aspect at different scales, derived variables to indicate the distance to sources of moisture and proximity to and characteristics of obstacles between these moisture sources and areas of snow accumulation, and canopy density. A weekly time step of snow telemetry (SNOTEL) SWE data from 1990 through 1999 was used. The most important variables were elevation and regional scale $\left(81 \mathrm{~km}^{2}\right)$ slope. Since the seasonal and inter-annual variability is high, a regression relationship should be formulated for each time step. The inter-annual variation in the relation between SWE and topographic variables partially corresponded with the amount of snow accumulated over the season and the El Niño Southern Oscillation cycle.

Keywords: Colorado River, SNOTEL, snow water equivalent, surface topography. 
S. R. FASSNACHT, K. A. DRESSLER, D. M. HULTSTRAND, R. C. BALES \& G. PATTERSON

RESUMEN.- Se analiza la relación entre el equivalente de agua en la nieve (SWE) y 28 variables (27 variables topográficas y otra basada en la densidad del dosel) para la Cuenca del Río Colorado, EE.UU. mediante regresión multivariante. Estas variables incluyen la localización, pendiente y orientación a diferentes escalas, además de variables derivadas para indicar la distancia a las fuentes de humedad y la proximidad a las barreras topográficas, además de las características de las barreras topográficas entre las fuentes de humedad, las áreas de acumulación de nieve y la densidad del dosel. Se utilizaron telemetrías semanales de nieve (SNOTEL) desde 1990 hasta 1999. Las variables más importantes fueron la elevación y la pendiente a escala regional $\left(81 \mathrm{~km}^{2}\right)$. Dada la alta variabilidad estacional e interanual, fue necesario establecer regresiones específicas para cada intervalo disponible de datos. $\mathrm{La}$ variación interanual en la relación entre variables topográficas y el SWE se corresponde con la cantidad de nieve acumulada a lo largo de la temporada y el ciclo de El Niño-Oscilación del Pacífico Sur.

Palabras clave: Río Colorado, SNOTEL, equivalente de agua en nieve, topografía.

\section{Introduction}

Many papers have illustrated the importance of snow as a water resource in mountainous regions (e.g., Viviroli et al., 2007). This is especially true in the western United States (US); much research has been conducted for this area to determine the distribution and changes in snowpack patterns (Dozier, 2011). To understand the distribution of snow in a specific region, it is often assumed that there is temporal consistency in the spatial snow patterns (Sturm and Wagner, 2010), so that relations can be developed between topographic variables and snowpack properties. The topographic variables are used as surrogates for the meteorological drivers, such as precipitation, wind for sublimation and redistribution, and short-wave radiation plus temperature (for long-wave radiation) for snowmelt. Since terrain in snow-covered regions varies only over geologic time, it can be assumed constant. Vegetation, in particular the presence and density of tree canopy coverage, influences local scale meteorology and can vary over shorter time periods.

Spatial correlations and variability in snow depth and snow water equivalent (SWE) have been related to topography for the purpose of producing SWE maps at various scales. Over a fine resolution of 30 to 100 metres covering up to several $\mathrm{km}^{2}$, Erxleben et al. (2002) considered elevation, slope, aspect, and topography related variables while Winstral et al. (2002) added two wind based topographic variables to map the distribution of snow. At a coarser resolution of $1 \mathrm{~km}$ covering hundreds of thousands of square kilometres, Fassnacht et al. (2003) used elevation alone, but interpolated SWE 
uniquely at each location (1-km pixel) from the surrounding snow telemetry (SNOTEL) data.

For coarse scale meteorological interpolation, the use of multiple topographic variables stems from large scale mapping of precipitation and temperature normals that Solomon et al. (1968) used for the Island of Newfoundland, Canada. This method has subsequently been used by Daly et al. (1997) in the Parameter-elevation Regressions on Independent Slopes Model (PRISM) to map climate normals for the US.

Together with the spatial variability in snowfall, there can be substantial temporal variability in snowfall for the same area (Serreze et al., 2001). Dozier (1989) stated that temporal and spatial snow cover variability must be assessed in order to understand the complex relations between snow cover, climate, and water resources. Across the Colorado River Basin SWE estimated from SNOTEL data vary seasonally and annually (Fassnacht et al., 2003). This paper aims to examine temporal patterns in the correlation between topography and SWE from SNOTEL data at a 1-km resolution, as used in Bales et al. (2008).

Since elevation and SWE are known to be highly correlated (Mitchell and Dubois, 1977; Fassnacht et al., 2003), this paper will examine the relation between SWE and other topographic variables, such as those used by Daly et al. (1997) and Seglenieks et al. (1999). These variables include location, slope, aspect, distance to ocean sources of moisture, obstacles that storm tracks meet, and canopy density. The objectives of this paper are as follows: 1) to identify seasonal and annual variations in the relation between topographic variables and SWE, and 2) to determine whether the variations are related to quantities of SWE and/or climate indicators for SNOTEL stations.

\section{Study area}

The study area is the Colorado River Basin in the southwestern US (Figure 1). Most of the snow accumulation in the study area is located in the Upper Colorado River Basin (drainage area 277,000 $\mathrm{km}^{2}$ ) which has an elevation range of $975-4260 \mathrm{~m}$ with an average elevation of $2150 \mathrm{~m}$. The Lower Colorado River Basin (drainage area $346,000 \mathrm{~km}^{2}$ ) has an elevation range of $24-3851 \mathrm{~m}$ and an average elevation of $1310 \mathrm{~m}$. Almost $60 \%$ of the upper basin, but only $16 \%$ of the lower basin, is above $2000 \mathrm{~m}$. Snow in the Lower Colorado River Basin accumulates along the Mogollón Rim in east-central 


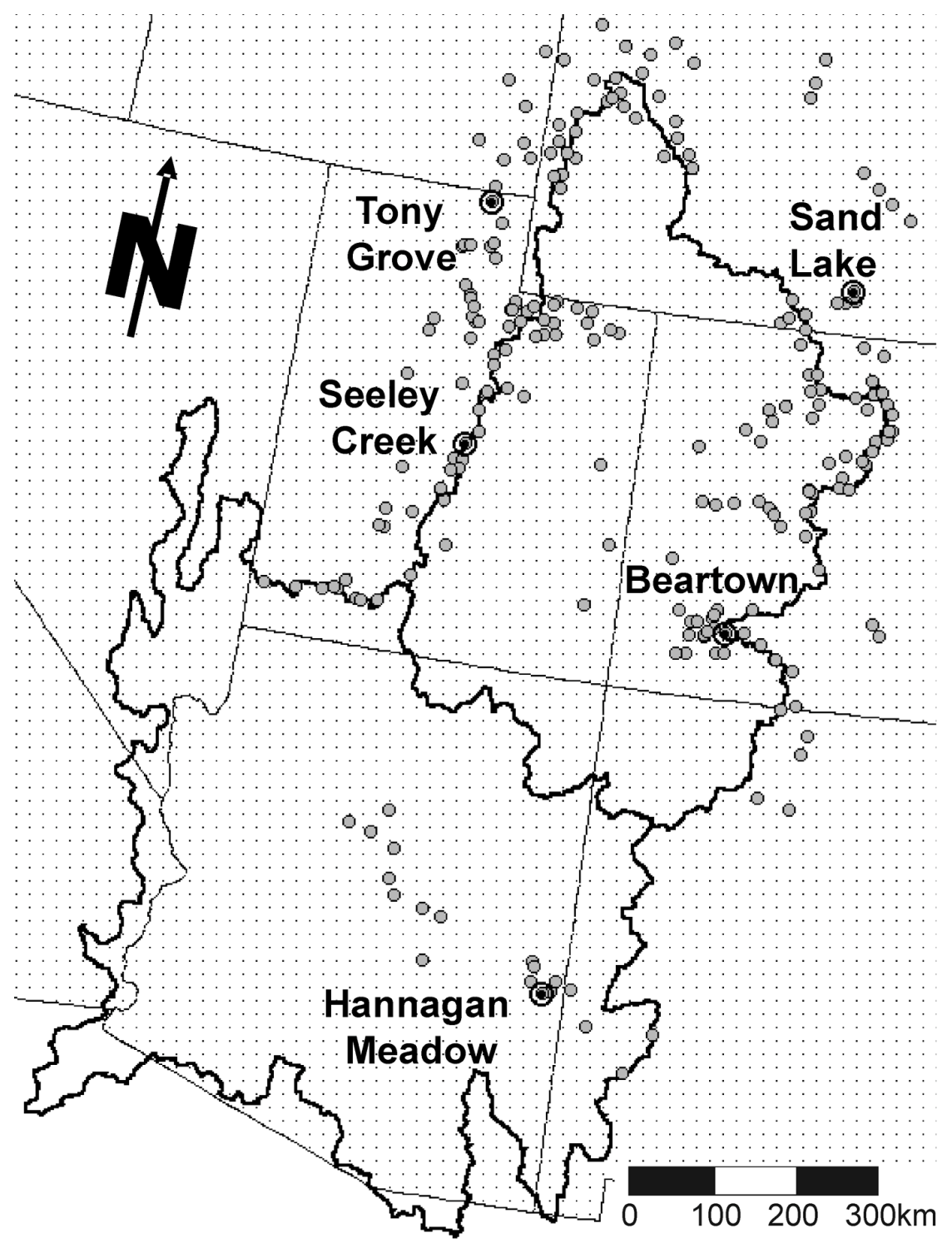

Figure 1. The Colorado River Basin in the Southwestern United States with the location of the snow telemetry (SNOTEL) stations. Sample stations that illustrate different climatic regions are labeled and highlighted with an encircled dot.

Figura 1. La Cuenca del Río Colorado en el suroeste de Estados Unidos con la ubicación de las estaciones de telemetría de nieve (SNOTEL). Se han etiquetado las estaciones de muestreo que ilustran las diferentes regiones climáticas y se destacan con un punto rodeado. 
Arizona, on the Colorado Plateau in the vicinity of the Grand Canyon, and in western New Mexico. Across the Colorado Basin there can be up to a threemonth difference in the timing of snowpack ablation, between the Arizona snowpack and higher-elevation, higher-latitude areas such as the San Juan Mountains in southwestern Colorado or the mountains of western Wyoming.

\section{Data and methods}

\subsection{Variables}

SNOTEL data have been collected at numerous locations throughout the Colorado River Basin since the late 1970s and additional stations came online in the mid to late 1980s and 2000s. Daily SWE data measured at 125 SNOTEL sites within the Colorado River Basin and 115 others proximate to the basin were used in this analysis. These data are collected by the Natural Resources Conservation Service (NRCS) (2003) using snow pillows, which are fluid-filled pressure sensors that measure the mass of the overlying snowpack (see Palmer, 1986; Johnson and Schaefer, 2002). To examine the seasonal and interannual relation of SWE with topographic variables, weekly intervals for the period from late December through late June for the 1990-1999 water years (October 1 through September 30) were used in the analysis.

The SWE data were filtered for potentially erroneous values using the methods described by Serreze et al. (1999). Specifically the following procedure was used for each station: if SWE data were missing for any of the first 15 days of October, the entire year was considered missing; if either the daily SWE or precipitation increment, computed from the cumulative recorded data, were missing, both were considered missing; if the daily change in SWE was greater than $254 \mathrm{~mm}$, the SWE value was considered potentially erroneous; if the daily change in SWE was greater than $63.5 \mathrm{~mm}$ and the change in SWE on the following day was greater than $63.5 \mathrm{~mm}$, but in the opposite direction, i.e., a gain followed by a loss or a loss followed by a gain, the SWE value was considered potentially erroneous. Means and standard deviations were computed for 60-day periods, and if individual SWE values differed from the 60-day mean by more than five standard deviations, such SWE values were considered potentially erroneous. Overall, less than 1 station per year was removed as a result of the filtering procedure.

Twenty-eight variables were used in the analysis, specifically, canopy density and 27 topographic variables, all based on $1-\mathrm{km}$ resolution data (Table 1 ). 
Table 1. Independent regression variables used in the analysis. Note: * the distance to the ocean, barrier height, barrier distance, and shield height were measured from the three directions: west, northwest and southwest.

Tabla 1. Variables independientes utilizadas en el análisis de regresión. * las distancias al océano, altura de las barreas, distancia a las barreras y su altura fueron medidas en tres direcciones: oeste, noroeste y suroeste.

\begin{tabular}{|c|c|c|}
\hline Variable name & Source & Original units \\
\hline Longitude & $\begin{array}{l}\text { X from Natural Resources Conservation } \\
\text { Service (NRCS) data }\end{array}$ & Decimal degrees \\
\hline Latitude & Y component from above (NRCS data) & Decimal degrees \\
\hline Elevation & $Z$ from DEM & meters \\
\hline Local slope & Sin slope $(\Delta z)$ from $1 \times 1$ pixels & - \\
\hline Local eastness & Sin aspect $(\Delta x)$ from $1 \times 1$ pixels & - \\
\hline Local northness & Cos aspect $(\Delta y)$ from $1 \times 1$ pixels & - \\
\hline West footprint slope & $\begin{array}{l}\Delta \mathrm{z} \text { from } 5 \text { column by } 3 \text { row pixels with } \\
\text { pixel of interest at column } 4 \text {, row } 2\end{array}$ & - \\
\hline West footprint eastness & $\Delta \mathrm{x}$ for west footprint & - \\
\hline $\begin{array}{l}\text { West footprint } \\
\text { northness }\end{array}$ & $\Delta y$ for west footprint & - \\
\hline South footprint slope & $\begin{array}{l}\Delta z \text { from } 3 \text { column by } 5 \text { row pixels with } \\
\text { pixel of interest at column } 2 \text {, row } 2\end{array}$ & - \\
\hline South footprint eastness & $\Delta y$ for south footprint & - \\
\hline $\begin{array}{l}\text { South footprint } \\
\text { northness }\end{array}$ & $\Delta x$ for south footprint & - \\
\hline Regional slope & $\Delta \mathrm{z}$ for $9 \mathrm{~km}$ swath around pixel & - \\
\hline Regional eastness & Regional $\Delta \mathrm{x}$ & - \\
\hline Regional northness & Regional $\Delta y$ & - \\
\hline $\begin{array}{l}\text { W/NW / SW distance to } \\
\text { ocean * }\end{array}$ & $\begin{array}{l}\text { Distance to ocean computed from west, } \\
\text { northwest, and southwest kilometers }\end{array}$ & $\begin{array}{l}\text { Kilometers } \\
\text { meters }\end{array}$ \\
\hline W/NW / SW barrier & Elevation difference between maximum & \\
\hline height * & barrier in direction of ocean and pixel & \\
\hline $\begin{array}{l}\text { W / NW / SW barrier } \\
\text { distance * }\end{array}$ & $\begin{array}{l}\text { Distance from maximum barrier in direc- } \\
\text { tion of ocean to pixel }\end{array}$ & $\begin{array}{l}\text { Kilometers } \\
\text { meters }\end{array}$ \\
\hline $\begin{array}{l}\text { W / NW / SW shield } \\
\text { height * }\end{array}$ & $\begin{array}{l}\text { Cumulative elevation increase between } \\
\text { ocean and pixel }\end{array}$ & \\
\hline Forest density & $\begin{array}{l}\text { US Forest Service density maps from } \\
\text { AVHRR imagery }\end{array}$ & $\%$ \\
\hline
\end{tabular}

The location of the SNOTEL sites is published by the NRCS (2003) to the nearest minute of latitude and longitude, which translates to approximately $+/$ $1 \mathrm{~km}$. Fortunately, more accurate Global Positioning System (GPS) coordinates, to the nearest second (approximately $+/-25 \mathrm{~m}$ ), were available for 
most sites from the NRCS State Snow Surveyors. Those sites without GPS coordinates retain the location accuracy of $1 \mathrm{~km}$.

The 27 topographic variables used in the analysis (Table 1) were derived from the US Geological Survey 1-km resolution hydrologically corrected (HYDRO1K) digital elevation model (DEM), acquired from the Land Processes Distributed Active Archive Center (2003). The 1-km resolution of the DEM data presents a potential problem of distortion and more specifically smoothing. However, with the exception of the local slope and aspect variables (discussed below), there is limited effect on the computation of the topographic variables due to the size of the study domain. Specifically, the net study area approaches $10^{6} \mathrm{~km}^{2}$ with, on average, one SNOTEL station per $3,000 \mathrm{~km}^{2}$, and an average distance between stations of $50 \mathrm{~km}$.

The station-based variables are the relative latitude and longitude, elevation, slope and aspect. The longitude and latitude are the $\mathrm{X}$ and $\mathrm{Y}$ locations from the standard USGS Albers projection. This projection uses the WGS84

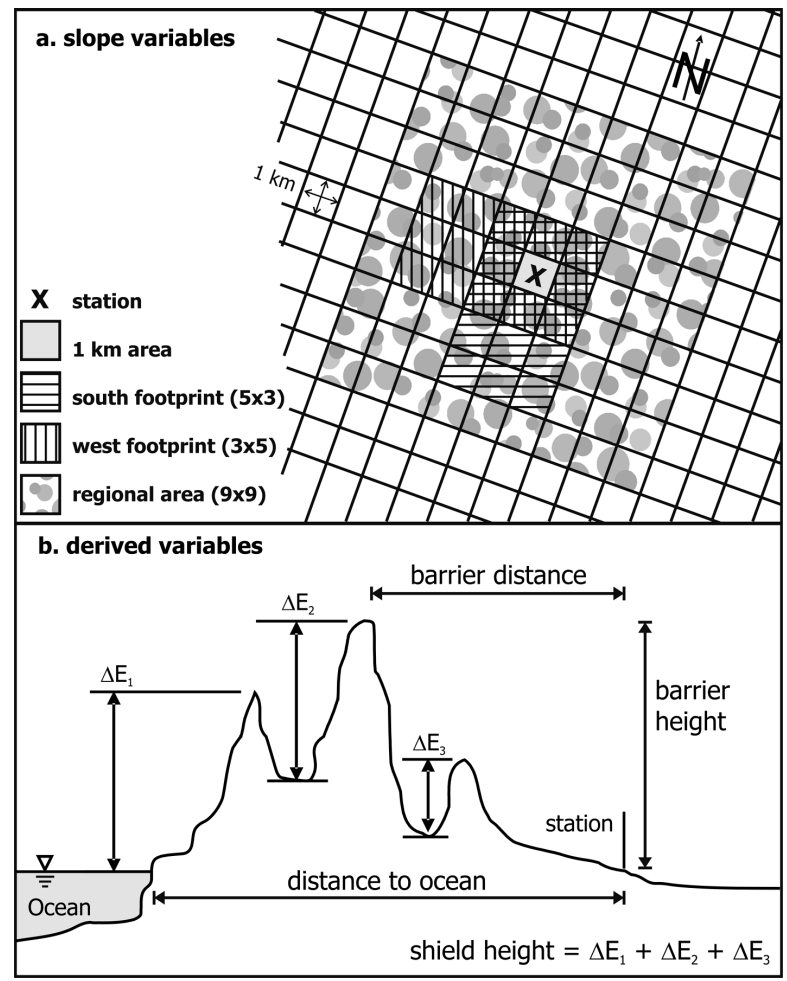

Figure 2. Schematic of a) slope variables, and b) derived variables. Figura 2. Esquema de a) algunas variables de pendientes y b) las variables derivadas. 
datum and spheroid, with the $1^{\text {st }}$ standard parallel at 29.5 degrees $\mathrm{N}$, the $2^{\text {nd }}$ standard parallel at 45.5 degrees $\mathrm{N}$, the central meridian at 96 degrees $\mathrm{W}$ and the latitude of the projection's origin at 23 degrees $\mathrm{N}$

The slope and aspect were integrated to yield a directional slope, a change in the $\mathrm{x}, \mathrm{y}$ and $\mathrm{z}$ directions. The abbreviation $\Delta \mathrm{z}$ denotes slope (computed as the sine of slope), $\Delta \mathrm{x}$ denotes eastness (computed as the sine of aspect), and $\Delta \mathrm{y}$ denotes northness (computed as the cosine of aspect). Three different scales of directional slope have been chosen: the local slope at a 1-km resolution, footprint slope (west and south facing), and a regional slope (Figure 2a). The footprints were considered from the west ( 5 columns by 3 rows with the station of interest in the $4^{\text {th }}$ column from west and $2^{\text {nd }}$ row north) or from the south ( 3 columns by 5 rows with the station of interest in the $2^{\text {nd }}$ column from the west and $4^{\text {th }}$ row from south). Essentially these are $3 \mathrm{~km}$ by $3 \mathrm{~km}$ blocks with an additional 2 sets of 3 blocks ( $2 \mathrm{~km}$ by $3 \mathrm{~km}$ ) to the west or the south (Figure 2a) to determine on which side of the mountain a station of interest is located (windward versus leeward side), which is very important for orographic precipitation. The regional slope is a $9-\mathrm{km}$ by $9-\mathrm{km}$ block centered about each station, as described by Seglenieks et al. (1999).

Three derived variables are the same as those generated by Solomon et al. (1968) and Seglenieks et al. (1999). The distance to ocean is a measure of the proximity to ocean, which represents the relation to the major source of moisture; the barrier height is the difference in the heights of the station of interest and that of the highest point between the ocean and the station of interest; and the shield height is the cumulative elevation rise from the ocean to the station of interest (Figure $2 b$ ). The barrier distance was added for this analysis. It is the distance from the station of interest to the highest point between the ocean and the station of interest. Seglenieks et al. (1999) considered the eight main compass directions and the station location compared to its sources of moisture. Since the snowpack is a cumulative record of precipitation under predominantly colder than freezing conditions, these derived variables were considered from the northwest, west, and southwest, i.e., the Pacific Ocean.

For each SNOTEL station, the canopy density was estimated from US Forest Service (2001) data. Canopy density was derived from the normalized difference vegetation index (NDVI) using a NOAA Advanced Very High Resolution Radiometer (AVHRR) dataset. NDVI is a greenness index computed from the ratio of the difference of the near infrared (AVHRR channel 2 for wavelengths from 0.58 to $0.68 \mu \mathrm{m}$ ) minus the red (AVHRR channel 1 for wavelengths from 0.725 to $1.1 \mu \mathrm{m}$ ) to the sum of the two channels. Land cover type was not used in the analysis. 
TEMPORAL INCONSISTENCIES IN COARSE-SCALE SNOW WATER EQUIVALENT PATTERNS:...

Table 2. Station information for five sample SNOTEL sites in or around the Colorado River Basin. Tabla 2. Información de las estaciones SNOTEL en la Cuenca del río Colorado.

\begin{tabular}{lccclc}
\hline Station id & $\begin{array}{c}\text { Longitude } \\
\text { [decimal } \\
\text { degrees] }\end{array}$ & $\begin{array}{c}\text { Latitude } \\
\text { [decimal } \\
\text { degrees] }\end{array}$ & $\begin{array}{c}\text { Elevation } \\
{[\mathrm{m}]}\end{array}$ & Station name & State \\
\hline 11H36S & -111.629 & 41.898 & 2642 & Tony Grove & Utah \\
$11 \mathrm{~K} 09 \mathrm{~S}$ & -111.433 & 39.31 & 3048 & Seeley Creek & Utah \\
06H23S & -106.281 & 41.463 & 3063 & Sand Lake & Wyoming \\
07M32S & -107.512 & 37.714 & 3536 & Beartown & Colorado \\
09S11S & -111.844 & 35.073 & 2749 & Hannagan Meadows & Arizona \\
\hline
\end{tabular}

\subsection{SWE-Topography Relations}

Weekly data from late December to late June for 10 years (1990-1999) were analyzed. A step-wise linear multi-variate regression between topographic variables and SWE was used on each weekly set of data. Starting with the variable having the largest correlation with SWE, additional variables were included in the regression in the order that gives the largest reduction in the error for the regression. This step-wise addition of variables was repeated until the addition of new variables did not increase the coefficient of determination $\left(\mathrm{r}^{2}\right)$ by more than $1 \%$. The order of inclusion of the variables and the final set of coefficients were recorded.

For comparative purposes, the coefficients for the normalized variables have been scaled; the logarithm has been taken of the absolute value coefficient and the original sign has been returned to the coefficient. Since the magnitude and sign of the coefficients varied, the winter period was divided into four periods for all years: accumulation was $12 / 29-3 / 23$, peak was $3 / 30$ $5 / 18$, ablation was 5/25-6/8, and late season was 6/15-6/29.

\section{Results}

Five stations (Figure 1 and Table 2) across the basin illustrate the variation in SWE for three years versus the average from 1990 to 1999 (Figures 3a-e). The study decade (1990 was missing for Sand Lake) was ranked for each of the five stations based on the annual peak SWE (Table 3). In general, 1997, 1995 and 1993 were high snow years, while 1990, 1992 and 1990 were low snow years. However, spatial variations exist. In the winter of 1999 there was low SWE in Arizona but average to high SWE elsewhere (Table 3). Lower than average SWE was observed in the northern areas in 1991 while less than aver- 
S. R. FASSNACHT, K. A. DRESSLER, D. M. HULTSTRAND, R. C. BALES \& G. PATTERSON

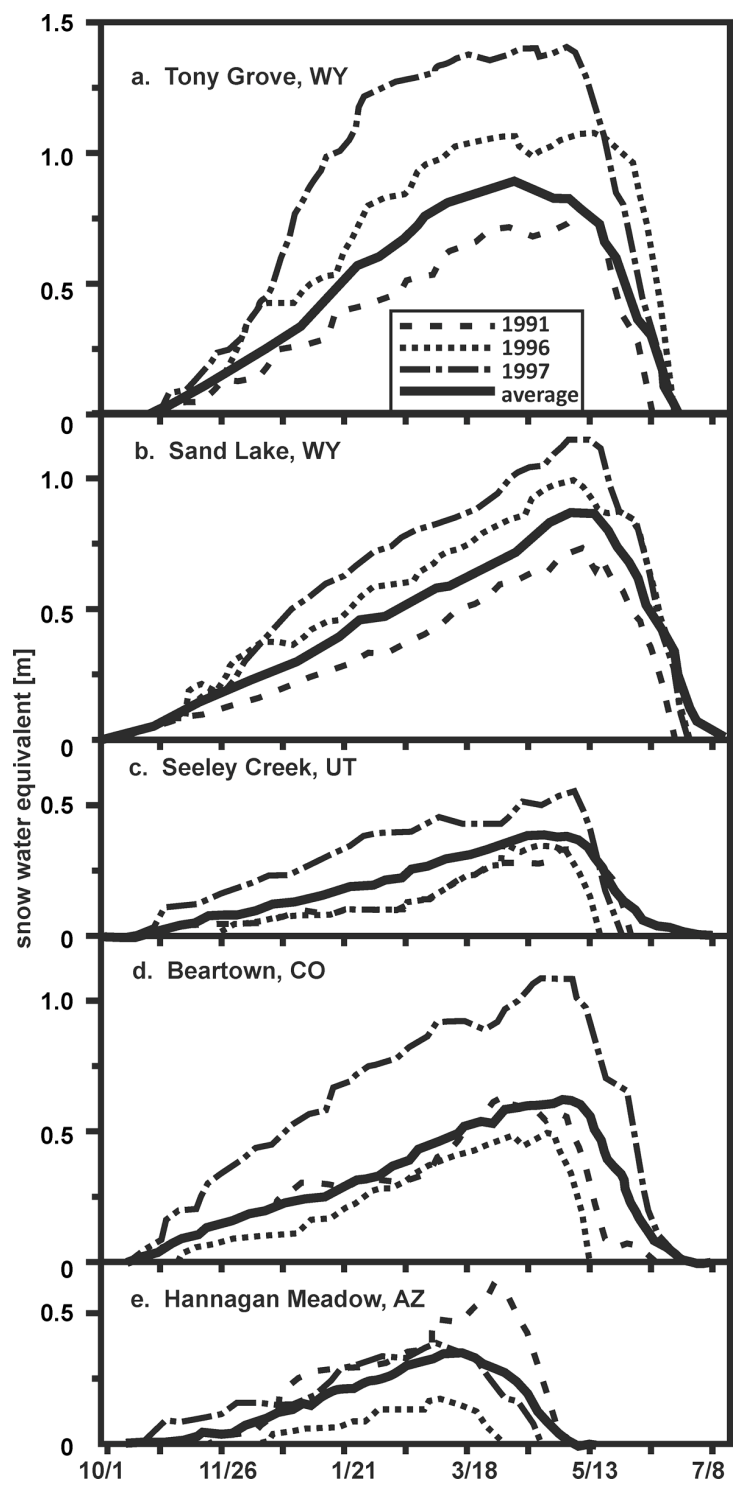

Figure 3. SNOTEL stations in and around the Colorado River Basin illustrating years of maximum, minimum and average snow accumulation a) Tony Grove Utah, b) Sand Lake Wyoming, c) Seeley Creek Utah, d) Beartown Colorado, and e) Hannagan Meadows Arizona.

Figura 3. Estaciones SNOTEL en la cuenca del Río Colorado ilustrando años de acumulación de nieve máxima, mínima y promedio a) Tony Grove Utah, b) Sand Lake Wyoming, c) Seeley Creek Utah, d)

Beartown Colorado, y e) Hannagan Meadows Arizona. 
TEMPORAL INCONSISTENCIES IN COARSE-SCALE SNOW WATER EQUIVALENT PATTERNS:...

Table 3. Ranking by year of the peak snowpack SWE for the 5 SNOTEL stations listed in Table 2.

Table 3. Rangos por años en la acumulación de nieve para las 5 estaciones indicadas en la tabla 2.

\begin{tabular}{lcccccccccc}
\hline & \multicolumn{10}{c}{ Rank } \\
\cline { 2 - 12 } Station name & 1 & 2 & 3 & 4 & 5 & 6 & 7 & 8 & 9 & 10 \\
\hline Tony Grove & 1997 & 1999 & 1998 & 1996 & 1993 & 1995 & 1991 & 1994 & 1990 & 1992 \\
Seeley Creek & 1995 & 1993 & 1997 & 1998 & 1999 & 1996 & 1991 & 1994 & 1992 & 1990 \\
Sand Lake & 1999 & 1997 & 1995 & 1996 & 1993 & 1994 & 1998 & 1991 & 1992 & N/A \\
Beartown & 1997 & 1995 & 1993 & 1999 & 1991 & 1990 & 1998 & 1994 & 1996 & 1992 \\
Hannagan & & & & & & & & & & \\
Meadows & 1993 & 1991 & 1998 & 1995 & 1992 & 1997 & 1994 & 1990 & 1996 & 1999 \\
\hline
\end{tabular}

Table 4. Order of inclusion ranking and statistics for regressions using all data, and the cumulative positive and negative coefficients.

Tabla 4. Orden de inclusion, rango y estadísticos de las regresiones utilizando todos los datos, y de los coeficientes positivos y negativos.

\begin{tabular}{|c|c|c|c|c|c|c|c|c|c|}
\hline \multirow{3}{*}{ Parameter } & \multicolumn{6}{|c|}{ Inclusion statistics } & \multirow{3}{*}{ Rank } & \multicolumn{2}{|c|}{$\begin{array}{l}\text { Cumulative } \\
\text { coefficients }\end{array}$} \\
\hline & \multirow[b]{2}{*}{ Net } & \multirow[b]{2}{*}{ Total } & \multirow[b]{2}{*}{ Occur } & \multicolumn{3}{|c|}{ Position } & & \multirow{2}{*}{\multicolumn{2}{|c|}{ Positive Negative }} \\
\hline & & & & Mean & High & Low & & & \\
\hline Longitude (x location) & 20 & 773 & 14 & 7.9 & 4 & 17 & 21 & 2.6 & -47.9 \\
\hline Latitude (y location) & 4 & 4328 & 62 & 3.4 & 1 & 16 & 7 & 194.5 & -13 \\
\hline Elevation & 1 & 5572 & 78 & 2.4 & 1 & 17 & 1 & 399.8 & 0 \\
\hline Local slope & 22 & 669 & 14 & 11.7 & 2 & 17 & 15 & 0 & -102.9 \\
\hline Local eastness & 27 & 261 & 5 & 7.9 & 5 & 10 & 27 & 0 & -7.6 \\
\hline Local northness & 14 & 1103 & 18 & 6.4 & 2 & 13 & 25 & 29.3 & -2.7 \\
\hline West footprint slope & 9 & 1886 & 30 & 7 & 2 & 18 & 4 & 261.9 & -1.8 \\
\hline West footprint eastness & 25 & 566 & 11 & 10.3 & 4 & 17 & 19 & 0 & -57.2 \\
\hline West footprint northness & 23 & 669 & 13 & 9.2 & 5 & 13 & 18 & 23.5 & -37.4 \\
\hline South footprint slope & 18 & 807 & 13 & 4.8 & 1 & 9 & 14 & 68.4 & -35.4 \\
\hline South footprint eastness & 19 & 781 & 15 & 9.8 & 2 & 18 & 17 & 76.6 & -1.3 \\
\hline South footprint northness & 24 & 626 & 12 & 6.7 & 2 & 16 & 20 & 55.6 & 0 \\
\hline Regional slope & 7 & 2581 & 43 & 7.1 & 2 & 17 & 2 & 397.3 & 0 \\
\hline Regional eastness & 21 & 707 & 14 & 9 & 4 & 20 & 11 & 114.6 & -2.3 \\
\hline Regional northness & 26 & 305 & 5 & 5.2 & 1 & 12 & 24 & 26.9 & -10 \\
\hline West distance to ocean & 12 & 1630 & 25 & 5.4 & 1 & 10 & 12 & 99 & -15.7 \\
\hline West barrier height & 3 & 4612 & 70 & 4.6 & 1 & 13 & 6 & 0.1 & -224 \\
\hline West barrier distance & 17 & 986 & 17 & 9 & 3 & 16 & 26 & 18.9 & -7.1 \\
\hline West shield height & 15 & 1032 & 18 & 6.9 & 2 & 15 & 22 & 0.7 & -49.2 \\
\hline NW distance to ocean & 13 & 1535 & 26 & 6.4 & 1 & 12 & 10 & 0 & -127.9 \\
\hline NW barrier height & 10 & 1859 & 31 & 6.8 & 1 & 15 & 13 & 7.8 & -96.8 \\
\hline NW barrier distance & 6 & 3282 & 53 & 5.6 & 2 & 15 & 9 & 166.3 & 0 \\
\hline NW shield height & 11 & 1682 & 27 & 6.9 & 1 & 18 & 16 & 38.9 & -47.1 \\
\hline SW distance to ocean & 8 & 2242 & 39 & 7.5 & 1 & 15 & 8 & 164.7 & -4.1 \\
\hline SW barrier height & 2 & 5253 & 78 & 4.2 & 1 & 11 & 3 & 0.1 & -300.9 \\
\hline SW barrier distance & 16 & 1023 & 21 & 9.8 & 6 & 19 & 23 & 42.5 & 0 \\
\hline SW shield height & 5 & 3341 & 54 & 7 & 3 & 16 & 5 & 2.4 & -221.7 \\
\hline Forest density & 28 & 100 & 2 & 8 & 3 & 13 & 28 & 5 & -1.7 \\
\hline
\end{tabular}


S. R. FASSNACHT, K. A. DRESSLER, D. M. HULTSTRAND, R. C. BALES \& G. PATTERSON
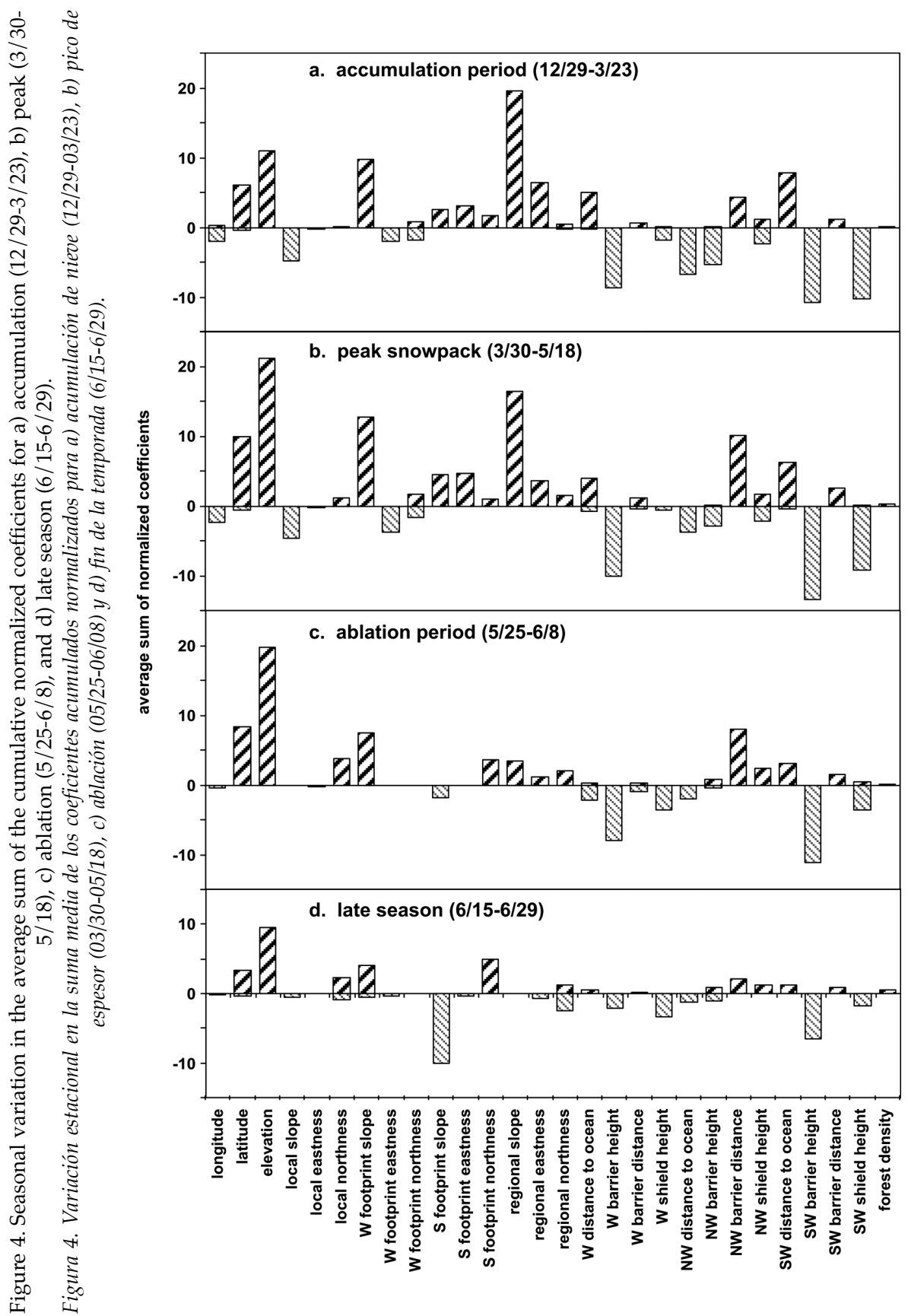
age peak SWE was observed in Arizona (Figure 3e). The year 1996 saw low to average SWE in the southern and central areas, with a slightly higher than average SWE in the north. In 1997, SWE was higher than average in all areas except Arizona (Figure 3a-e).

The analysis determined the order in which variables were included in the regressions. For each variable a total score for all regressions was computed based on the order of inclusion, to consider a possible differing number of variables in a specific regression. For each week, the variable regression score was 29 minus the inclusion position so that the most correlated variable would have a variable regression score of 28 while the last included variable could have a variable regression score of 9 (at most 20 variables were included in a regression). When a variable was not included its variable regression score was zero. The net rank presented in Table 4 is based on the total score. The six highest ranked variables for inclusion were: elevation, southwest barrier height, west barrier height, latitude, southwest shield height, and northwest barrier distance.

The seasonal variations in the regression coefficients are presented in Figure 4a-d. The overall magnitude of positive coefficients is largest in the peak snowpack period (Figure $4 \mathrm{~b}$ ) and smallest in the late season (Figure 4d); it is $80 \%$ of the peak during the accumulation, $63 \%$ during ablation, and $31 \%$ late in the snow season. However, the cumulative negative coefficients are the same for the first two snow periods and then reduced to 60 and $57 \%$ of the peak during ablation and late season (Figure $4 \mathrm{c}$ and $4 \mathrm{~d}$ ). The largest positive coefficients are regional slope, elevation, west footprint slope, latitude, northwest barrier distance and southwest distance to the ocean. Overall the magnitude changes as the snow season progresses. The largest negative coefficients include west and southwest barrier height, and southwest shield height, with the south footprint slope being important late in the season (Figure $4 d$ ).

Interannual variations in the magnitude and size of the regression coefficients (Figure 5a-j) are not as prominent as the seasonal variations (Figure 4ad). The most important variables have large coefficients for most years, as illustrated in the different seasonal periods. However, the dominant variables are not important for all years. For example, regional slope is quite important in 1900, 1993, 1994, 1996 and 1997, but not at all 1992 and barely in 1995 and 1998. The larger negative coefficients are more temporally consistent than larger positive coefficients. Specifically these are west and southwest barrier height, and southwest shield height. The presence of both positive and negative coefficients occurs less often for the annual averages than for the seasonal averages. The size of the average cumulative coefficients in Figure 4a-d and 
5a-j is different since each is a sum of negative or positive coefficients for a period (season or year) and there is a different number in each category, otherwise, the average for each period would be misrepresented.

\section{Discussion}

For the entire study decade, $65 \%$ of the coefficient values are represented by elevation, regional slope, southwest barrier height, west footprint slope, southwest shield height, west barrier height, latitude, southwest distance to ocean, and northwest barrier distance (Table 4). Elevation always has the strongest influence on the distribution of SWE (Fassnacht et al., 2003), as the net magnitude of the cumulative elevation coefficients and its inclusion rank are both first (Table 4). The ranks for the next eight most important variables are similar for inclusion and coefficient magnitude. However only SW shield height and SW distance to the ocean had the same ranks for both at 5 and 8 , respectively (Table 4). Regional slope has the second largest cumulative coefficient but is only the $7^{\text {th }}$ most included variable, indicating its importance when included in a regression. Some lesser important variables have similar positive and negative cumulative coefficients (Table 4).

The variables that have large net positive or negative coefficients for the study decade (Table 4) do not always have large coefficients for each individual year (Figure 5). However, there is consistency among some of the variables and they are important in each and almost all years. Therefore, separate regression equations are necessary for each year, and due to the seasonal variations, they are necessary for each individual time step.

How representative the SNOTEL network is of its surrounding terrain must be assessed. Elevation is the least representative of basin topography (Figure 6a) and of the topography within the maximum snow-covered extent (Figure $6 \mathrm{~b}$ ) defined by Bales et al. (2008). The slopes of the SNOTEL stations are underrepresented at the flatter slopes, and overrepresented at moderate slopes (Figure 6a-b); stations are typically situated on flat terrain, but still in transitional areas. The footprint slopes are least representative, compared to the local and regional slopes (Figure 6a-b).

The scale of influence of slope is important (Liston, 1999). For this analysis the coarsest scale, i.e., regional slope, was relevant, as was the medium scale west footprint slope. The latter indicates the side of the mountain on which a station is located with respect to orographic effects. Due in part to the orientation of mountains, the south footprint slope was generally not important. The finest scale slope, i.e., local scale, was also not important. 
TEMPORAL INCONSISTENCIES IN COARSE-SCALE SNOW WATER EQUIVALENT PATTERNS:...

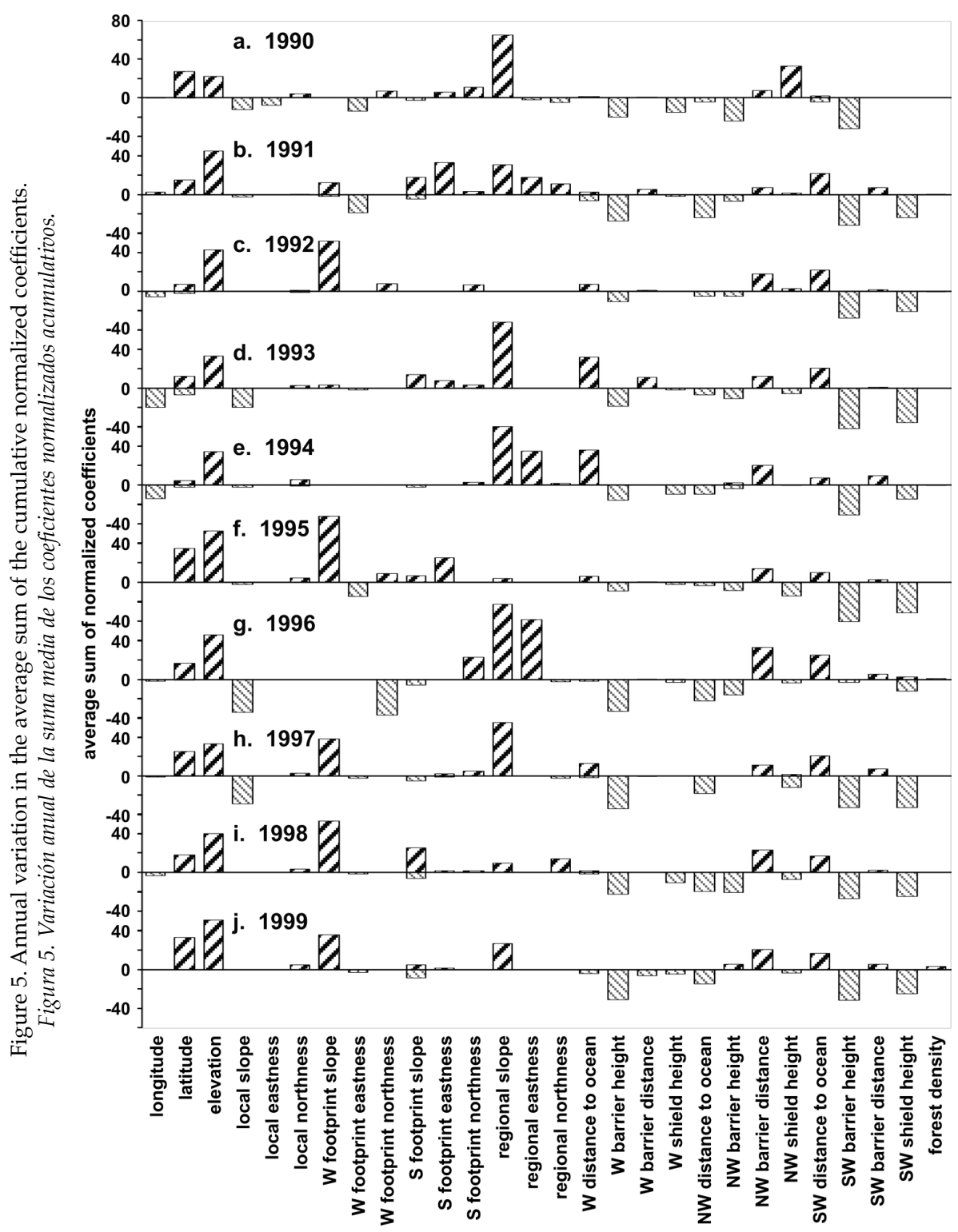


Overall, the southwest variables are more important than the west or northwest derived variables. There is a larger variation in the southwest derived variables across the study domain. As well, snow accumulation in Arizona, New Mexico, and southern Colorado are influenced by the storm tracks from the southwest.

Canopy density is the least important variable. However, the multi-variate regression variables are indicative of climate that brings the snow to an area and enables the snowpack to accumulate and persist, and this climate also influences the vegetation growth regime. The poor correlation between canopy density and SWE was observed since other topographic variables act as surrogates for vegetation (e.g., Repass, 2005).

The magnitude of the dominant variables changes over the snow season (Figure $4 a-d$ ) and from year to year (Figure 5a-j). The temporal variations for separate variables exist for shorter time periods than shown in Figure 4a-d. There is also variation in inclusion of the variables, yet some of the main variables appear consistently. A monthly time step was appropriate for density since the rate of increase was mostly consistent over space and time (Mizukami and Perica, 2008). From October through March, Mizukami et al. (2011) found that SWE regressions with some of the topographic variables used here and gridded meteorological variables were adequate on a monthly basis if the Western U.S. were divided into five regions. Our results show that separate regression equations should be used for each step. However, only the top 10-15 variables should be considered, as some cross-correlation exists between these variables and lesser important variables.

The largest net sum of coefficients were for 1994 through 1996 (Figure 5df), with the smallest being 1997, 1990 and 1993 (Figure 5h, a, d). This does not correspond with the high and low snow years (Table 3). However, the correlation between the topographic variables and snow water equivalent on a winter by winter basis (Table 4) is in part a function of the variable climate of the western US. The lowest correlations were for 1991, 1993, and 1998, all of which were periods of El Niño (weak, moderate and strong) that followed at least half a year of El Niño (Meyers et al., 1999). However, 1992 was a strong El Niño year (Meyers et al., 1999) yet April exhibited higher than average correlations. The remainder of the year showed less than average correlations. Two years with higher than average correlations (1996, and 1999) were in the La Niña cycle (Meyers et al., 1999), with the periods of highest correlation starting earlier than usual, that is, starting in January or February as opposed to April (Table 3). These two years were preceded by a La Niña fall (Meyers et al., 1999). Higher than average correlations were also observed for 1990, which was preceded by and in a neutral El Niño Southern Oscillation (ENSO) 


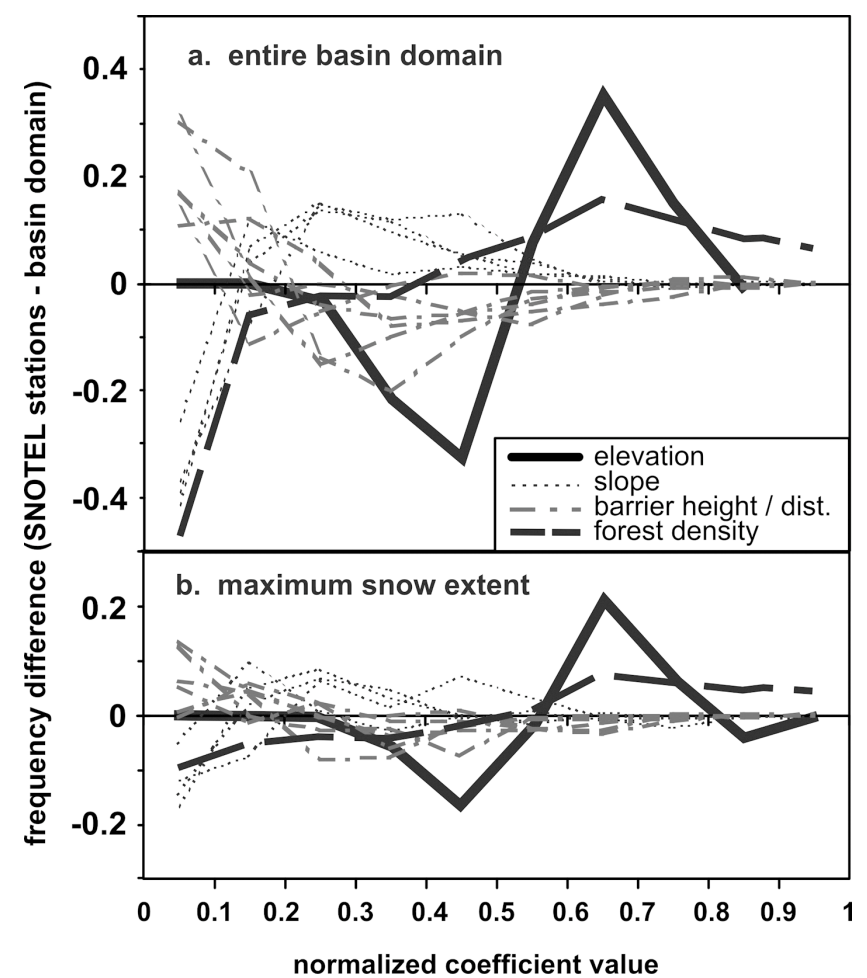

Figure 6. Difference in the distribution of variables between the SNOTEL stations with a) the topography of the Colorado River Basin, and b) the basin topography within the maximum snow extent, as defined by Bales et al. (2008) using AVHRR SCA imagery.

Figura 6. Diferencia en la distribución de las variables entre las estaciones SNOTEL a) topografía de la cuenca del Río Colorado, y b) topografía de la cuenca dentro de la extensión superficial máxima de la nieve, según la definición de Bales et al. (2008) utilizando imágenes AVHRR SCA.

cycle. The winter of 1995 was at the tail end of an average El Niño cycle (Meyers et al., 1999) and illustrated greater than average correlations starting in late April and continuing until June. Overall, Cayan (1996) and Clark et al. (2001) found that the El Niño corresponded to less than average April 1 snowcourse SWE in the northern parts of the Upper Basin, i.e., Wyoming and northern Utah, and greater than average April 1 snowcourse SWE in the Lower Basin. Trends were less discernible in the southern parts of the Upper Basin, i.e., Colorado, due to the magnitude of variability (Clark et al., 2001). Marquínez et al. (2003) report similar results in determining that topographic variables derived at the sub-basin scale significantly improved identification 
of heterogeneity in precipitation patterns. The climate associated with the SNOTEL data (e.g., Fassnacht and Derry, 2010) can be used to sub-divide areas that follow different annual accumulation and melt patterns.

\section{Conclusions}

Topographic variables that act as surrogates for the meteorological drivers were correlated to SWE. For the Colorado River Basin, the relation between SWE and these topographic variables varied seasonally and annually over the period of 1990 through 1999. Weekly SWE data were used over the winter season of December $29^{\text {th }}$ through June $29^{\text {th }}$, and the multi-variate regressions usually varied from week to week.

The multi-variate approach enabled us to describe approximately 50\%, 65\%, and $25 \%$ of the spatial variability of the SWE during the accumulation, peak, and ablation periods, respectively. While the particular variable that was most important to SWE distribution varies both seasonally and annually, regional slope and elevation were consistently two of the key variables. Several of the derived variables are also important, including SW shield height, all barrier heights (NW, W and SW), NW and SW barrier distance, and latitude.

While trends were observed, these variations were not directly correlated to high (1993, 1995 and 1997) and low (1990, 1992 and 1994) snow years, nor the ENSO cycle. Due to the seasonal and annual variability of the $\mathrm{SWE} /$ topography relation, it is necessary to formulate the regressions for each time step. However, while the topographic variables were chosen to represent the entire Colorado River Basin and the variability in the snow accumulation across the basin, the resulting relation to the state of ENSO (El Niño versus La Niña) illustrates that the regressions should be examined for smaller sub-basin areas to better examine cold season precipitation patterns and therefore, SWE.

\section{Acknowledgements}

Thanks are due to Frank Seglenieks of Environment Canada who supplied some of the coding that provided the basis for the analysis, and who was always available for consultation. Global Positioning System coordinates for most of the SNOTEL sites were provided by NRCS Utah State Snow Surveyor, Randy Julander, and NRCS Colorado State Snow Surveyor, Michael Gillespie. The initial research was supported by the NASA Earth Observation System Southwest Regional Earth Science Applications Center (NASA grant NAG990005). 
TEMPORAL INCONSISTENCIES IN COARSE-SCALE SNOW WATER EQUIVALENT PATTERNS:...

\section{References}

Bales, R.C., Dressler, K., Imam, B., Fassnacht, S. \& Lampkin, D.J., 2008. Fractional snow cover in the Colorado and Rio Grande basins, 1995-2002. Water Resources Research, 44(W01425), doi:10.1029/2006WR005377.

Cayan, D.R., 1996. Interannual climate variability and snowpack in the western United States. Journal of Climate, 9: 928-948.

Clark, M.P., Serreze, M.C. \& G.J. McCabe, 2001. Historical effects of El Nino and La Nina events on the seasonal evolution of the montane snowpack in the Columbia and Colorado River Basins. Water Resources Research, 37(3): 741-757.

Daly, C., Taylor, G. \& Gibson, W., 1997. The PRISM Approach to Mapping Precipitation and Temperature. Proceedings of the 10th Conference on Applied Climatology, Reno, NV, American Meteorological Society, p10-12.

Dozier, J., 1989. Spectral signature of alpine snow cover from Landsat Thematic Mapper. Remote Sensing of the Environment, 28: 9-22.

Dozier, J., 2011. Mountain Hydrology, Snow Color, and the Fourth Paradigm. EOS Transactions, 92(43): 373-374.

Dressler, K.A., Fassnacht, S.R. \& Bales, R.C., 2006. A comparison of snow telemetry (SNOTEL) and snowcourse measurements in the Colorado River Basin. Journal of Hydrometeorology, 7(4): 705-712.

Erxleben, J., Elder, K. \& Davis, R., 2002. Comparison of spatial interpolation methods for estimation snow distribution in the Colorado Rocky Mountains. Hydrological Processes, 16: 3627-3649.

Fassnacht, S.R., Dressler, K.A. \& Bales, R.C., 2003. Snow water equivalent interpolation for the Colorado River Basin from snow telemetry (SNOTEL) data. Water Resources Research, 39(8), 1208, (doi:10.1029/ 2002WR001512).

Johnson, J.B., \& Schaefer, G., 2002. The influence of thermal, hydrologic, and snow deformation mechanisms on snow water equivalent pressure sensor accuracy. Hydrological Processes, 16(18): 3529-3542 (doi: 10.1002/hyp.1236).

Land Processes Distributed Active Archive Center, 2003. HYDRO1k - Elevation Derivative Database. United States Geological Survey and National Aeronautic and Space Administration Distributed Active Archive Center, URL: <http://edcdaac.usgs.gov/gtopo30/hydro/>.

Lo, F., \& Clark, M.P., 2002. Relations between spring snow mass and summer precipitation in the southwestern United States Associated with the North American Monsoon System. Journal of Climate, 15: 1378-1385.

Meyers, S.D., O'Brien, J.J. \& Thelin, E., 1999. Reconstruction of monthly SST in the tropical Pacific Ocean during 1868-1993 using adaptive climate basis functions. Monthly Weather Review, 127(7): 1599-1612. 
Mitchell, K., \& Dubois, P., 1977. Gravity. In High Class in Borrowed Shoes, Anthem Publications ANR-1-1007, Toronto, Canada.

Mizukami, N, \& Perica, S. 2008. Spatiotemporal Characteristics of Snowpack Density in the Mountainous Regions of the Western United States. Journal of Hydrometeorology, 9: 1416-1426, [doi: http://dx.doi.org/10.1175/ 2008JHM981.1]

Mizukami, N., Perica, S.\& Hatch, D., 2011. Regional approach for mapping climatological snow water equivalent over the mountainous regions of the western United States. Journal of Hydrology, 400(1-2): 72-82, [doi: http:/ / dx.doi.org/10.1016/j.jhydrol.2011.01.019].

NRCS, 2003. SNOTEL (SNOwpack TELemetry). National Water and Climate Center Brochure, United States Department of Agriculture, $<$ www.wcc.nrcs.usda.gov>.

Palmer, P.L., 1986, Estimating snow course water equivalent from SNOTEL pillow telemetry: an analysis of accuracy, in Proceedings of the 54th Western Snow Conference, pp. 81-86.

Repass, J.W., 2005. Assessment of Digital Land Cover Maps for Hydrological Modeling of the Yampa River Basin, Colorado, USA. Unpublished M.S. thesis, Watershed Science, Colorado State University, Fort Collins, Colorado, USA, 103pp + 9 appendices.

Seglenieks, F.R. Soulis, E.D., Solomon, S.I., Kouwen, N. \& Lee,M., 1999. Development of Gridded Monthly Precipitation and Temperature Normals for Canada. Poster presentation at the scientific meeting of the Canadian Geophysical Union, Banff, Alberta, Canada, May 9-13.

Serreze, M.C., Clark, M.P., Armstrong, R.L., McGuiness, D.A. \& Pulwarty, R.S., 1999. Characteristics of the western United States snowpack from snowpack telemetry (SNOTEL) data. Water Resources Research, 35(7): 21452160.

Serreze, M.C., Clark, M.P. \& Frei, A., 2001. Characteristics of large snowfall events in the montane western United States as examined using snowpack telemetry (SNOTEL) data. Water Resources Research, 37(3): 675-688.

Solomon, S.I., Denouvilliez, J.P., Chart, E.J., Woolley, J.A. \& Cadou, C., 1968. The use of a square grid system for computer estimation of precipitation, temperature, and runoff. Water Resources Research, 4(5): 919-929.

Sturm, M., \& Wagner, A.M., 2010. Using repeated patterns in snow distribution modeling: An Arctic example. Water Resources Research, 46: W12549, [doi:10.1029/2010WR009434].

US Forest Service, 2001. Forest land distribution data for the United States. URL: $<$ http://http://www.srsfia.usfs.msstate.edu/rpa/rpa93.htm>.

Viviroli, D., Durr, H.H., Messerli, B., Meybeck, M \& Weingartner, R., 2007. Mountains of the world, water towers for humanity: Typology, mapping, 
TEMPORAL INCONSISTENCIES IN COARSE-SCALE SNOW WATER EQUIVALENT PATTERNS:...

and global significance. Water Resources Research, 43: W07447, [doi:10.1029/2006WR005653].

Winstral, A., Elder, K., Davis, R.E., 2002. Spatial Snow Modeling of Wind-

Redistributed Snow Using Terrain-Based Parameters. Journal of Hydrometeorology, 3: 524-538. 